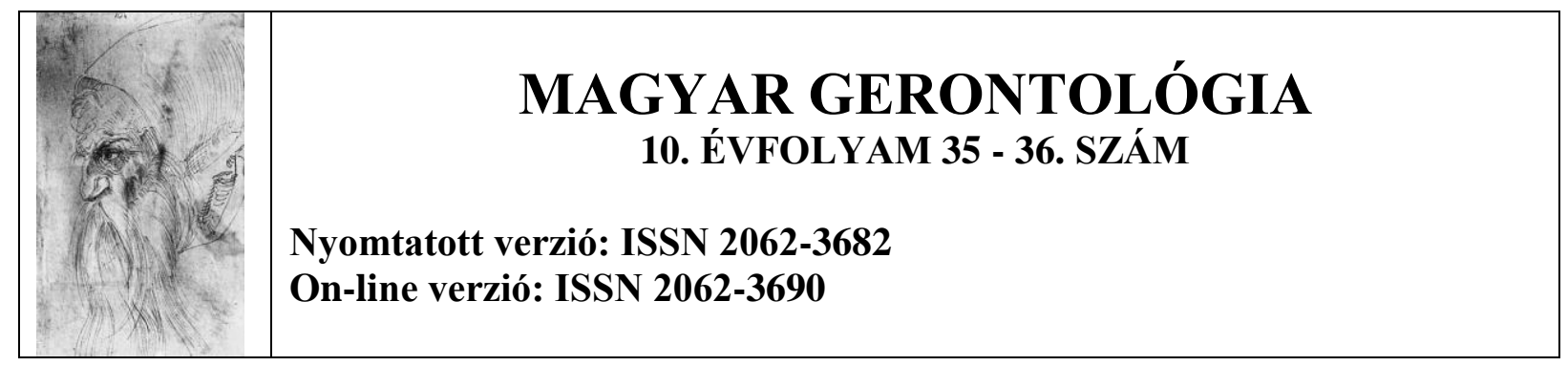

\title{
AZ IDŐSKOR JOBB MEGÉLÉSE TUDATOS DÖNTÉSEINKEN MÚLIK
}

A gerontológia társadalmi aspektusai a XXI. sz. 2. évtizedében Magyarországon

\section{Szanyi Mária}

Kulcsszavak: időskor, lelki, testi, hanyatlás, megállítás

\section{Összefoglalás}

A szerző kiscsoportos testi- és - szükség esetén-lelki foglalkozásokkal segíti megmutatni az utat az időskor minél további jobb megéléséért, és az egészség fenntartásáért.

\section{Summary}

The author helps to show the path towards better experience of old age and to maintain health with small-group sessions focusing on physical - and if needed on mental - health.

\section{Bevezetés}

Az időskorúak arányának növekedésével egyre hangsúlyosabb figyelmet kapnak - 60 éves kor felett- az időskori kórképek, és ezen belül a pszichiátriai megbetegedések - a demencia és a depresszió. Magyarországi felmérés: (2015) Az idősek 45\%-nál enyhe, vagy középsúlyos mértékben diagnosztizáltak depressziót. Kopp, Skrabski, Czakó felmérése szerint 1990-ben a 16 éven felüli lakosság 24,3\% a 60 év felettiek 41\%-ban voltak érintettek a depresszió tüneteiben. Ez a betegség az idős ember életminőségét nagymértékben rontja. Az idő előre haladásával egyébként is elkerülhetetlenek a veszteségek az idős ember számára: az egészsége megromlása, különféle testi panaszok fájdalmak, csökkent munkaképesség,a nyugdíjas lét feldolgozása, kapcsolatok elvesztése, stb. 


\section{AZ IDŐSKORI PASSZÍV FIZIKAI-, ÉS PSZICHIKAI ÉLETMÓD KÖVETKEZMÉNYEI}

SZENTGYÖRGYI ALBERT: "Minden élettelen fizikai rendszer a használatban megy tönkre.

Az élő rendszereket viszont a tétlenség teszi tönkre, míg a használatban fejlődnek. Az emberi sejtek az aktivitás hiánya miatt csenevészesednek, sorvadnak."

\section{Fizikai passzivitás:}

- az izomsejtek leépülnek

következmény : gyengeség

- az idegsejtek száma csökken

- romlik a mozgáskoordináció és az egyensúly érzékelés

- romlik a látás, hallás, érzékelés, észlelés

=> következmények: sérülések, betegség

\section{Pszichés passzivitás:}

- az életmóddal együtt járó változások

- feleslegesség érzés

- visszahúzódás

=> következmények: leépülés, demencia

\section{Pszicho-szociális változások:}

- szociális kapcsolatok elsorvadása

- az önbecsülés leépülése

Mindezek betegségre predesztinálnak /Dr.Popper Péter: Elköteleződés a betegséggel/

\section{AZ INAKTIVITÁS A ROMLÁS ÉS A LEÉPÜLÉS LEGFŐBB RIZIKÓ-FAKTORA}

$\mathrm{Az}$ életenergiát nem fogyasztani kell, hanem táplálni és szinten tartani. Az izomrostok fogyását megállítani, sőt rendszeres testedzéssel fokozni is lehet.

KURT TEPPERWEIN: " A játék kezdetén mindenki kap egy ÉLETET és egy játék-figurát TESTET és egy maximális JÁTÉKIDÖT (120 év). A játék során bármit megtehetünk, de a következményeket nekünk kell vállalni!"

Az öregedés és a szenilitás majdhogynem összetartozó fogalomként él a köztudatban.

Pedig a személyiségfejlődés nem áll le, hanem élethossziglan tart:

- ha végezzük azokat a tevékenységeket, melyek segítik az időskori elmét karban tartani,

- ha folyamatosan gyakorlunk valamilyen szellemi tevékenységet,

- ha rendszeres testmozgást iktatunk a mindennapjainkba,

- ha megtartjuk szociális aktivitásunkat, kapcsolatainkat,

- ha megörizzük szeretet kapcsolatainkat, 
- ha képesek vagyunk életkorunknak megfelelő produktumokra, hogy ne csökkenjen önbecsülésünk és szabadságunk, akkor megvalósítjuk az emberi lét alapvető célját és funkciójának legteljesebb gyakorlását, azaz Arisztotelész boldogság fogalmát. Mindez az érett személyiség jellemzője, mely képes megvalósítani önmagát bármely életkorban.

"Aki egyfolytában elereszti a füle mellett a meghallani valót, és behunyja szemét a látnivaló előtt az ne csodálkozzon, ha egy napon elhagyja Öt a hallása és a látása"

„Mikor ismerjük már el, hogy a betegség csak azt teszi meg értünk, amit magunk nem teszünk meg magunkért."

\section{(KURT TEPPERWEIN)}

És még egy Kurt Tepperwein történet:

Egyszer egy riporter megkérdezett három öreg embert, a hosszú élet titkáról. Az első ember azt mondta:

- Én minden nap keményen dolgoztam és minden nap elszívtam egy-egy pipát.Néha ittam hozzá egy pálinkát is.

- No és mennyi idős?

- 98-felelte.

A második ember így felelt:

- Én mindég mértékletesen étkeztem, rendszeresen sportoltam, és sportolok is mind a mai napig.

- No és hány éves?

- Én is 98 vagyok.

A riporter akkor megkérdezte a legöregebbnek látszót aggastyánt.

Az így felelt:

- Én láncdohányos vagyok, soha nem sportoltam, gyülölöm a mozgást, és minden egészségügyi szabályt!

- No és hány éves?

- 46 vagyok!

Ha testi - lelki harmóniában élünk, akkor jó a közérzetünk. Ha pozitív az érzelmi állapotunk, az jobb egészségügyi mutatókkal jár együtt. A WHO meghatározása: Az egészség a testi, 
lelki, társas, szociális és társadalmi egészség! Az egészséges életmódot bármely életkorban újra lehet kezdeni, az egészségi, edzettségi állapot 30-40 \%-ot javulhat. Az izomrostok újra épülnek, a tüdö-kapacitás növekszik, az állóképesség is javul. Jobb az anyagcsere javulnak az alvási szokások, valamint a mozgást is pozitív érzések kísérik.

\section{MELY MOZGÁS FORMÁT CÉLSZERÜ VÁLASZTANI, IDÖSKORBAN?}

A hosszabb testi passzivitás következtében nagy a valószínüsége annak, hogy test-szerte kisebb nagyobb fájdalmak, beszükült ízületek, rossz testtartás jellemzi az idős embert. Jellegzetes leggyakoribb panaszokat a hát, nyak és derékfájás, az ízületi fájások a lábfejek és a kézfejek deformációja, fájásai okozzák. Nőknél gyakori - a felső háti és nyaki gerincszakasz meghajlása, az un. "banyapúp".

- a hajlékonyság hiánya

- megromlott mozgás koordináció

- az egyensúly érzékelés megromlása /a leggyakoribb háztartási balesetek előidézője/

- az elgyengült izomzat

- a megrövidült szalagok és izomzat funkcionális zavara

Férfiaknál leggyakrabban - a has körfogat növekedése a "sörhas" és szövődményei

- párosulva még néhány rizikó faktorral

- valamint a nőknél említettek bármelyike lehetséges.

Amennyiben a fizikai aktivitás több éve szünetelt, akkor biztonságos és nem túl megterhelő mozgással ajánlott kezdeni, mint például:séta, kocogás, szobakerékpározás, úszás, vízi-torna. E mozgások javítják az állóképességet, megmozgatják az izmokat, ízületeket. Később tornaterembe tervezett gerinctorna, és fokozatos izom-erősítés mozgáskoordinációt és egyensúly - érzékelést fejlesztő, ízületeket nyújtó és erősítő gyakorlatokat végezhetnek. A jóga, a callanetics, a pilátesz mindegyikét lehet az időskorúak "teherbírására méretezni".

Légzést, tüdőkapacitást regeneráló, állóképességet helyreállító, fogyókúrát segítő gyakorlatokkal lehetőleg zenével, lehetőleg életkorban és hasonló kondícióban lévő társakkal kiscsoportban lehet a legjobb eredményeket elérni. Az idősebb sportolni vágyóknak is nagyon ajánlatos és eredményes a bodyART. Az első lépésektől fokozatosan látványos eredményeket lehet vele elérni. A terhelés adagolása kis lépésekben a gyakorlatok színes sokaságával élményt okoz a gyakorlónak. A mozgáskoncepció megalkotója Alexa Lé és Robert Steinbacher gyakorlatanyagát az alábbiak figyelembe-vételével állította össze. A terápiás gyakorlatokkal a gerinc és az ízületek élettanilag szükséges mozgását biztosítja, a helytelen 
testtartást és a rosszul beidegzett mozgásokat korrigálja és segít a rugalmasság visszaszerzésében. A légzés helyes bekapcsolásával javítja az agy és az izmok oxigén ellátását

- Az embert, mint funkcionális egységet tekinti a tréningben.

- A statikus és a dinamikus elemeket megfelelő sorrendbe rendezi.

- A gyakorlatsor egymásba kapcsolódó folyamatos egységet alkot.

A hangsúly nem az egyes izomcsoportokon van, hanem a test egészén. Az agy két féltekéjének összehangolt müködését fejleszti. Fokozatosan fejleszti az erőt, és az egyensúlyérzékelést. A gyakorlatsor felépítése az energia intenzitásának fokozatos növelésével majd csökkentésével az edzés befejezésével - más edzésformáknál nem tapasztalt - kellemes testilelki harmonikus állapotot eredményez. A negatív stressz a gyakorlat végére levezetődik, az energia visszatöltődik. A súlyfelesleg csökken, az alak formálódik. Számtalan variációja lehetővé teszi, hogy bármilyen korú és edzettségi állapotú személy végezheti. A gyors eredmény minden gyakorlót további edzésre sarkall. Az izomerő és az állóképesség javítása, fenntartása az időskori csontritkulást és csonttöréseket megelőzheti. Jobb a stressz türőképesség és az alvás is. Pozitívabb az énkép, nagyobb az önbecsülés. Az időskori labilisabb járást is késlelteti és az elesés kockázata is kisebb. A magyarországi bodyArt jogok tulajdonosai Lencsés Rita és Borsodi Balázs nagy súlyt fektetnek arra, hogy az edzőik szakszerüen, önmagukat képezve és szakértelemmel és megfelelő körülmények között végezzék az edzés munkát és szakmailag tökéletesen felkészült edzők foglalkozzanak minden korosztállyal.

Végezetül még két idézet:

BOERHAVE holland orvos: "A késői öregségig meg kell tudni örizni a test töretlen egészségét, és a szellem állandó élénkségét és nyugalmát. Ilyen állapotban majd egyszer betegség és küzdelem nélkül a test és a lélek egymásnak búcsút mond."

Paracelsus: "Az egészség nem minden, de egészség nélkül semmit sem ér az egész. „, 


\section{Szakirodalom:}

1. Allport /1961/ A személyiség érettsége

2. Erikson /1959/ Pszichoszociális fejlődés elmélet

3. Kopp Mária Magyar lelkiállapot 2002

4. Kurt Tepperwein: Testünk üzenetei

5. Lencsés Rita és Borsodi Balázs bodyArt: Oktatási füzetek

6. Maslov /1968/ Szükséglet hierarchia

7. Rüdriger Dahlke: A lélek nyelve a betegség

8. S Molnár Edit /2006/Életmód és közérzet az idősödés korában

9. Vajda Miklós A depresszió

\section{Szanyi Mária}

pszichológus, pedagógiai- és munkapszichológiai szakpszichológus, testnevelő tanár, jóga oktató, bodyArt instruktor I-II. fokozata

Munkahely: magánvállalkozó.

Miskolc, 3530 Arany János u.2.II/1. szanyimari@ gmail.com 46/415615 20/9777311 